AYNUR PALA

Okan University, Turkey

\title{
INVESTIGATING THE RELATION BETWEEN TECHNOLOGY AND ECONOMIC GROWTH WITH AK MODEL: AN APPLICATION SWAMY'S RANDOM COEFFICIENT MODEL (RCM)
}

\begin{abstract}
:
This study aims to investigate effect of technology on economic growth in thirthty-OECD countries using random coefficient model (RCM) with AK model. We applied cross-sectional dependence test, panel unit-root test and co-integration test. As a result of estimated RCM model, in Denmark, Finland, Germany, Ireland and Poland, researcher and Business enterprise expenditure on R\&D (BERD) as a percentage of GDP have positive and statistically significant effect on economic growth. In Estonia, Iceland and Latvia, researcher variable has positive and statistically significant effect on economic growth. In Turkey, BERD as a percentage of GDP variable has positively impacted on economic growth.
\end{abstract}

\section{Keywords:}

technology, economic growth, random coefficient model

JEL Classification: A19, C59, C50 